\title{
Spending, school structure, and public education quality. Evidence from California
}

\author{
Michael L. Marlow \\ Department of Economics, California Polytechnic State University, San Luis Obispo, CA 93407, USA
}

\begin{abstract}
This paper examines school structure, spending, and performance relationships in California and finds considerable support for the public exchange model that predicts that greater competition improves student performance. The evidence indicates that, despite claims to the contrary by many advocates of public education, higher education spending does not raise student achievement. Education spending is also shown to be highest in those counties exhibiting highest monopoly power as measured by the Herfindahl index. Strong support is also shown for the public exchange view that higher market power leads to lower student achievement in the fourth and eighth grades, but little support is shown for the tenth grade.
\end{abstract}

\section{Introduction}

A common perception is that US public schools perform poorly and that conditions are worsening over time. Until recently, the predominant view toward reversing the perceived performance decline was to raise overall spending, enabling expansion of staff and salaries, capital improvements, professional staff development, school construction and maintenance, and adoption of new technologies such as computers. An alternative viewpoint argues that problems are primarily a product of the monopoly position of the public school system. ${ }^{1}$ US public

\footnotetext{
${ }^{1}$ Other viewpoints emphasize school choice vouchers and charter schools. Those who believe that the public school system is a monopoly protected from competition - both by private schools and by neighboring public schools - often advocate school vouchers. Charter schools are outside the control of local school boards and may ignore state education codes, as well as develop their own curricula.
}

schools provide $90 \%$ of primary and secondary education in a public market that has experienced a dramatic reduction in numbers of school districts - from 108,579 to 14,556 over $1942-1992 .{ }^{2}$ This paper examines how the structure of the public school system influences both education spending and student performance. A model of public exchange provides the framework for hypothesizing how voters and education policy makers exchange with one another within school districts. The relation between school district structure and spending is shown to be an empirical matter because a high concentration of school districts may lower spending if scale economies are experienced, but as concentration rises, spending may rise as well as policy makers exploit enhanced monopoly powers. This paper also examines whether higher spending remedies performance problems.

School structure, spending and performance relation-

\footnotetext{
${ }^{2}$ Data on number of school districts obtained from various issues of Census of Governments, US Bureau of the Census.
} 
ships in California are examined. California is a state that appears to mirror national trends, but at the same time is at the forefront of national concern. ${ }^{3}$ The California public school system (primary and secondary) is the nation's largest with 1002 school districts, employing over 410,000 workers servicing over 5.3 million pupils with funding of $\$ 32$ billion in 1996-97. California has also experienced a dramatic rise in student population over 1.2 million since 1983-84, which represents more students than currently served by 42 other states. Previous studies often rely on cross-state examination, but this approach ignores differences in budgetary institutions across states. For example, California's Proposition 98 of 1988 guarantees minimum levels of state support for all schools and is an important determinant of school spending levels. Because each state has its own budgetary institutions and mandates, cross-state examination may incorrectly conclude that variation in spending or performance is caused by various factors (e.g., differences in school structure, demographics or income) when that variation results from differences in budgetary institutions. This paper avoids this problem by testing hypotheses only on data from California. ${ }^{4}$

\section{Public education markets}

\subsection{Model of public exchange}

External benefits may explain why many citizens advocate a strong governmental presence in elementary and secondary education. ${ }^{5}$ External benefits arise when there are third-party beneficiaries, such as the community and state, when education is produced and consumed. Because private suppliers cater only to demands of primary beneficiaries, a market failure arises whereby the private market under-provides education in the sense that

\footnotetext{
3 The following statistics are provided by the California Department of Education and the California Legislative Analysts' Office.

${ }^{4}$ Focus on a single state is also consistent with the argument of Hanushek, Rivkin and Taylor (1996) that empirical studies should focus on comparing all schools within a school district, or all school districts within one state. They find that the biases introduced by aggregation to state-level data inflate the effects of school resources on performance. While the present study examines data on counties, this may not be subject to much aggregation bias because counties are the location of school boards in California. Moreover, school finance is mostly centralized at the state capital, thus removing much of the funding factors that might arise when counties or school districts are given greater autonomy to self-finance their own programs.

${ }^{5}$ Lott (1987) offers an alternative view that public schooling provides the means to indoctrinate students to views that policy makers believe they should believe.
}

marginal social benefits outweigh marginal social costs. Of course, while public provision may remedy the market failure, public market provision may also over-provide in the sense that marginal social costs outweigh marginal social benefits. ${ }^{6}$ A symptom of over-provision is over-funding of public education.

The financing of public education explains why public schools dominate the supply of education. Public education is funded through all taxpayers, and individual tax bills are unrelated to whether taxpayers have children attending public schools and to the numbers of schoolage children. This is simply a consequence of the abilityto-pay principle of taxation whereby tax bills are not assigned on the basis of benefits received from policies. Presence of third-party beneficiaries may also partly explain why all taxpayers share financing burdens. In any event, primary recipients of public education are essentially charged zero unit prices under this tax method. In contrast, private education is funded according to the benefits principle of finance whereby unit prices reflect non-zero marginal (private) costs of education provision. Private education therefore carries a unit price that far exceeds the zero unit price of public education and, as a result, public education dominates the education market, thus leaving the private market relatively small and perhaps not a particularly strong competitor to public education. Public education therefore dominates the total (private and public) market, with relatively little competition from the private market. ${ }^{7}$ Until school vouchers or other policies significantly break the price advantage, the public market will most likely continue to dominate the education market.

A public exchange model has voters and policy makers exchanging with one another within a public education market that is segmented into school districts. Voters and parents signal preferences to policy makers in ways that include dealing directly with teachers, principals, school boards, and PTAs, as well as voting for politicians with compatible views. ${ }^{8}$ Exit options, or "voting-with-your-feet" as developed in Tiebout (1956), are last resorts when, for instance, dissatisfied parents move from one school district to another as they search for desired education policies. A system of competing school districts provides parents with choices that create incentives for policy makers to be responsive to parental preferences for quality education.

\footnotetext{
${ }^{6}$ See, for example, Sonstelie (1982).

7 An expanding literature on private schools is evolving; see West and Palsson (1988), Hamilton and Macauley (1991), Martinez-Vazquez and Seaman (1985), Couch, Shughart and Williams (1993), and Newmark (1995).

8 These options are discussed in Hirschman (1970). For a more detailed examination of the roles of voice and exit see Marlow (1992). This paper's public exchange model in education follows the framework developed in Marlow (1997).
} 
Evidence supports the notion that communities are concerned about the quality of their public schools. Black (1997) uses housing prices to infer the value parents place on school quality, where school quality is proxied by elementary school test scores. She infers values by looking within school districts along only one dimension: the elementary school the child attends. After controlling for school financial inputs and neighborhoods, higher test scores are found to be associated with higher housing prices; a 5\% increase in test scores leads to $2.1 \%$ rise in house prices. Black (1997) concludes that this relationship demonstrates that parents are sensitive to apparently small differences in school performance, as measured by housing prices. Of course, all homeowners, with or without school-age children, will tend to be concerned as well because of the connection between the quality of local schools and housing prices.

There is also evidence that supports the notion that not all parents, or communities, prefer the same type of public school system. Areas that have greater variation in economic characteristics, or preferences, of residents are shown to have greater numbers of school districts than those with less variation. Fisher and Wassmer (1998) examined school districts in the 167 largest metropolitan areas in 1982 and find that there are more smaller local districts when the differences among citizens with regard to desired government services expands. That is, in order for there to be relatively few school districts, citizens must display relatively little diversity in preferences for the mix of government services provided. This view is reinforced in Martinez-Vazquez, Rider and Walker (1997) who find that income, age, and racial variation in communities play a role in determining numbers of school districts. These studies suggest that greater variation of preferences among residents leads to greater choices in public education providers. Greater variety in choices will be reflected in policies as well as sizes of schools and districts.

School district options, or choices, play a pivotal role in establishing the degree of leverage that parents exercise over school teachers, administrators and staff. Fleeing to competing districts jeopardizes funding bases of school districts that lose students and is akin to private suppliers losing customers to competitors that offer better products or lower prices. Ease of fleeing is related to proximity of competitors as well as number of alternative suppliers. With relatively few competitors, the Leviathan view of Brennan and Buchanan (1980) predicts that policy makers will pursue budgets and behaviors reflecting their narrow interests, as opposed to those of parents and taxpayers. The range of interested policy makers includes teachers, union officials, and school staff. Higher spending associated with lack of competition may therefore reflect higher salaries, shorter working hours, more teaching assistants, more paid holidays, and other forms of compensation that may not be directly related to student performance. This view is consistent with Niskanen's (1971) theory of bureaucracy whereby government policy makers maximize functions other than profits, such as non-pecuniary income - obviously an issue for public education since policy makers do not operate under a profit-maximization constraint. ${ }^{9}$

There is some evidence that indicates that public education spending may not always be directed toward improving student performance. Duplantis, Chandler and Geske (1995) find that unionization and collective bargaining are reasons behind cost escalation in public education. Kurth (1987) finds that the presence of teachers' unions exerts negative influences on test scores. Hoxby (1996) concludes that teachers' unions increase school inputs (e.g., teacher salaries, per-student expenditures, and teacher-student ratios), but reduce productivity sufficiently to raise drop-out rates. Unionization may therefore partially explain why public schools can simultaneously cost more and perform more poorly over time. However, unionization effects are probably not important in the present study since California is a heavily unionized state and therefore little inter-county variation in unionization should exist. It should also be noted that Eberts and Stone (1984) find that union schools are more productive (based on pre- and post-test scores) than non-union schools for the average elementary student. Therefore the evidence is mixed on the effect of unionization on school performance.

Within the public education market of California there appears to be untapped potential for extensive competition between and within school districts. There are over 7700 public schools within over 1000 school districts and 57 counties. However, in most cases, parents have very limited choices about which school they may send their children to since they are assigned a particular school within their district. ${ }^{10}$ "Exclusive territories" create monopolies within districts whereby parents must move to other neighborhoods if they wish to send their children to better schools, even though moves may only be a block or so from present locations. This arrangement restricts exit options, thus reinforcing monopolistic power stemming from how financing systems crowd-out private schools. The public exchange model predicts that Leviathan policy makers take advantage of monopoly power, as revealed by over-expanded budgets and relatively low student performance. This model also predicts

\footnotetext{
9 On the bureaucracy issue in public education, Anderson, Shughart and Tollison (1991) find that states with relatively large numbers of administrative personnel also have lower student achievement on standardized tests and higher drop-out rates. However, Brewer (1996) finds that the number of administrators does not exert negative impacts on student achievement in New York schools.

${ }^{10}$ West (1990) discusses this issue.
} 
that greater public funding will not necessarily improve performance since it is likely that spending hikes will be diverted away from uses that are most closely connected to student performance.

\subsection{Counterviews: scale economies and shared taxation}

A competing view is that quality improvement simply requires higher funding and an emphasis on greater competition may raise spending as smaller public schools/districts are less able to exploit scale economies. However, while economies of scale may arise in education, past consolidation of districts does not appear to have been prompted by attempts to lower costs. Kenny and Schmidt (1994) argue that attempts to exploit scale economies are one of three factors that explain school district consolidation over 1950-1980. The other two factors are state aid growth, which lowered quality differences between districts, and growing powers of teachers' unions using consolidation to lower costs of organizing memberships.

Another counterview is Rivlin's (1992) argument that inter-governmental competition mostly leads to fights over which jurisdictions can lower tax burdens the quickest. Competition has two defects according to this view: it results in tax revenues that do not meet the needs of governments (i.e., under-taxation) and it reinforces the fact that jurisdictions have unequal resources. ${ }^{11}$ Rivlin (1992) proposes "uniform shared taxes" as a correction whereby (state) governments pool tax revenues and then return them with some emphasis on redistributing revenues from richer to poorer states. Shared taxation removes taxpayer incentives to flee governments on the basis of "high" tax policies because local governments have little control over tax policies when all governments share taxes set at uniform rates. Because this framework assumes that governments will then only compete on the basis of benefits provided rather than taxes levied, social welfare is predicted to rise. This view also assumes that benevolent, as opposed to Leviathan, policy makers do not exploit enhanced monopoly powers that arise from shared taxation, but simply focus on providing higherquality programs through enhanced revenue-raising abilities.

How a system of shared uniform taxation would influence behavior is clear under the public exchange model. Shared taxation protects and increases monopoly positions of governments since it prevents governments

11 While Rivlin (1992) makes the case against inter-governmental competition between state governments, the general case appears to be about governmental competition and therefore could be applied to competition between school districts as well. from competing on the basis of tax policies, thus effectively creating one large monopoly government from which taxpayers/citizens may not easily escape. Selfinterested policy makers then operate under enhanced monopoly positions that contribute to lower-quality, more costly programs. The public exchange model therefore predicts that shared taxation contributes to performance that falls below what would arise under a system of many governments, or private schools, each of which competes for tax revenues, private tuition revenues and students.

\subsection{California's system of shared taxation}

Much of school finance in California is a product of shared taxation. ${ }^{12}$ While 25 years ago local school districts were mostly funded by locally derived revenues, funding decisions are now dominated by budgetary decisions made in the state capital of Sacramento. These decisions are influenced by Propositions 13 and 98, with the latter passed in 1988 and mandating minimum funding guarantees for kindergarten through community colleges. Proposition 98 constraints now account for roughly $80 \%$ of total funding. Perhaps the most important budgetary constraint is that imposed by the Serrano vs. Priest ruling of 1972 in which the Supreme Court of California required restructuring of the school finance system to virtually eliminate spending differences between school districts on the basis of wealth. The California legislature then imposed revenue limits on districts and provided $\$ 2.4$ billion in additional funding for poorer school districts. In effect, court rulings mandated that school finance be tied to a system of shared taxation whereby the state government was responsible for collecting taxes from local governments and then returning revenues to school districts on the basis of various factors such as numbers of students and redistribution to poorer districts. This system therefore limits the abilities of local school officials to make funding decisions and constrains inter-district competition by limiting the ability of school districts to demonstrate that they use local funds wisely, since funding comes from a common base in Sacramento. This funding arrangement may lead to a commons problem whereby lack of property rights to tax dollars leads to over-use of the revenue base since providers of tax dollars are not necessarily the ones primarily benefiting from use of those tax dollars. ${ }^{13}$

\footnotetext{
${ }^{12}$ See California Legislative Analyst's Office (1995) for a discussion of school finance.

13 Wagner (1992) refers to a fiscal process where choice is divorced from liability, taxes or public debt, as one of "fiscal irresponsibility" and creates a "commons" institutional setting that promotes over-spending.
} 
Of course, many school districts - especially wealthy ones - did not particularly like shared taxation whereby portions of local tax revenues flowed to other school districts. Fischel (1988) argues that Proposition 13 was caused by Serrano since it allowed high-property-value school districts/counties to bypass some of the redistribution (from high- to low-property-value counties) required by Serrano. Proposition 13 capped property tax rates and growth in assessed value, reducing by $54 \%$ the amount of property taxes available to fund services provided by cities, counties, school districts, and other government agencies. Silva and Sonstelie (1995) find that Serrano created some equalization across school districts, but also is partially responsible for some of the decline in average funding per student across California. In a comprehensive study of school finance in 1992-93, the US General Accounting Office (1997) finds that, while most states attempt to equalize funding across school districts, wealthier districts in 37 states had more total funding than poor districts, after controlling for differences in geographic and student-needs-related costs such as special education. The imbalance averaged $24 \%$ on a per pupil basis across states, with California needing to shift $35 \%$ more state funds from wealthy to poor or middle-class districts in order to meet equalization criteria. The imbalance appears to be a result of wealthier districts supplementing their shared tax revenue with fees and parental contributions as well as political forces in the redistribution process in Sacramento.

\section{Hypotheses}

The public exchange model predicts that price advantages that public schools enjoy over private schools and exclusive territory constraints within school districts discourage competition. Although Serrano has not brought perfect equality of funding in California, it created a system of shared taxation that supports a monopolistic public school market. Public education is therefore predicted to exhibit behaviors consistent with the model of public exchange within a setting of monopoly; i.e., school districts with few or no competitors should be out-performed by districts with more competitors.

Another hypothesis is that spending and performance are not necessarily directly related. One reason for ambiguity is that, since local government control over finances is imperfect under shared taxation, policy makers and local taxpayers have little incentive to be costconscious in a setting where funding dollars come from a communal and statewide funding pool. Coupled with Niskanen's (1971) theory of bureaucracy whereby monopoly governments maximize functions other than profits, higher funding is not necessarily a sign of higherquality education. Downes (1996) finds evidence that California school districts had monopoly power before and after Proposition 13, although somewhat less after Proposition 13. Evidence of monopoly behavior was that administrators substituted improved student performance for greater numbers of administrative staff.

Local taxpayers may also believe that, at the margin, higher local spending may be funded from taxpayers of other areas since all school districts compete against one another for communal statewide funds. Under shared taxation there may be less resistance at the local level to oppose spending increases since local funding levels are now less related to local tax burdens. Within this setting, taxpayers may not be particularly vigilant in their efforts to control excessive spending, and possibly may lobby for spending growth on the assumption that their tax bills will rise less than local gains in spending. Moreover, a Niskanen (1971) asymmetric information problem may exist whereby state officials, or local taxpayers/parents in our application, experience high monitoring costs and lack of private market counterparts with which to assess arguments that school district officials make for higher funding. Such a setting suggests that higher spending will not necessarily indicate higher-quality education and further contributes to ambiguity about the spending-performance relationship. Higher spending may simply reflect higher monopoly power and therefore may be associated with either higher or lower performance. The spending-performance relationship is therefore ambiguous and we cannot rule out that higher spending is simply a function of greater monopoly power, or even that an inverse relation between spending and performance arises when spending is relatively high, and performance relatively poor, as a result of monopoly power.

\section{Testing methodology}

\subsection{Performance measures}

Appropriate measurement of school performance is obviously important as parents need good information by which to base schooling choices and policy makers need to somehow determine which schools perform well and which perform poorly. While spending used to be the most commonly used barometer of performance, the empirical evidence makes clear that education spending, by itself, is a poor gage of how well schools educate students. Hanushek's (1986) survey of 65 studies concludes that little connection between inputs and output exists and even the few studies that find a significant effect from spending also find that effects are mostly trivial in magnitude.

Several studies have measured effects of schools on students through subsequent earnings of those students. This approach assumes that the effect of a school on a student is ideally one that lasts a lifetime. However, evidence provided by Betts $(1995,1996)$ and Grogger 
(1996) indicates little effect of school resources, such as spending and class size, on subsequent earnings. Unfortunately, this evidence suggests that performance of public schools may be worse than previously thought since students do not appear to gain the ability to earn higher incomes later in life when we raise school spending or other inputs today - thus suggesting that resources are not used wisely. The evidence, however, is mixed on this issue, as Card and Krueger $(1992,1996)$ argue that higher spending raises labor market outcomes of students.

Perhaps the growing interest in class-size reduction is a result of growing awareness by the public and policy makers that higher spending, by itself, is not the way to solve the problems of public education. Hanushek (1998) notes that proposals for class-size reductions are a rallying point for parents, teachers, and administrators across the nation, and politicians have rushed to claim credit for introducing policies aimed at reducing class sizes. The pupil-teacher ratio, for example, is frequently becoming the fundamental metric for quality which has begun replacing spending per student as the common measure of adequacy and equity. There is little evidence, however, that class size exerts any systematic effect on student performance, although it certainly is related to overall costs. While it appears to be commonsense that lower class sizes should be associated with higher student performance, Hanushek (1998) concludes that the empirical evidence does not strongly support this belief.

The evidence on class size is, however, mixed. Eberts and Stone (1984) find that class size is an important factor explaining school performance. It is also possible that research that finds no relation between class size and performance is based on class sizes that are larger than what educators believe can make a significant difference. Glass and Smith (1978), for instance, show that reductions in classes that contain below 21 students exert significant effects, but little effect occurs in larger classes. Perhaps this explains why class sizes of 20 and below are often the goal of policies seeking to lower class size in elementary schools. This view also suggests that previous research showing no relation between class size and student performance is a result of class sizes being too large to demonstrate benefits of class-size reduction.

The teacher-student ratio is examined here because parents commonly view class size as an important performance gage. It is an easily observed measure and it is also likely that responsive administrators will respond to apparently strong parental preferences for small classrooms. The hypothesized relationship is ambiguous between teacher-student ratios and the degree of competition in the public education market. More competitive markets may tend to have more teachers per student, as school policy makers are hypothesized to be more responsive to parental preferences for smaller class sizes when they operate under more competitive conditions than when they operate in less competitive markets. It is also likely that if administrators and staff prefer to receive income in the form of salary and benefits rather than in smaller class sizes, they may also prefer larger class sizes as the hiring of additional teachers means fewer dollars for themselves. If true, this also means that less competitive markets allow this preference to be more fully exploited, thus suggesting that, as markets become more monopolistic, class sizes rise as measured by falling teacher-student ratios. However, even though administrators and staff may prefer larger class sizes so as to receive higher salaries, they may be constrained in their efforts to divert income to themselves in this manner. Salaries, for instance, are highly observable and therefore may receive greater public scrutiny than other forms of compensation such as benefits, class sizes, and paid holidays. The relationship between teacher-student ratios and monopoly power is therefore an empirical question.

In 1993, the average teacher-student ratio at the county level was $0.048 .{ }^{14}$ The average classroom was therefore composed of 20 students per teacher. The range for the teacher-student ratio was 0.083 to 0.04 , and the median value was 0.046 .

Test scores on standardized tests are also examined. While test scores on standardized tests have been frequently used to measure student achievement, Summers and Wolfe (1977) argue that the distribution of test scores should somehow be accounted for in order to appropriately gage performance. This argument is based on the observation that students in the tails of the distribution typically receive the marginal dollar of school expenditures, either through special services or classes for disadvantaged, special or gifted students.

The CLAS Grade Level Performance Assessments were administered to fourth, eighth, and tenth graders throughout California during school year 1993-94 and covered reading, writing, and mathematics. There are six performance levels, 1 through 6 , with performance level 6 being the highest. Table 1 displays the percentage of students achieving at or above performance level $4-\mathrm{a}$ measure used by the California Department of Education as its common measure of school performance. For grade 4 , the following percentages of students achieved at least level 4: $21.58 \%$ (reading), $29.23 \%$ (math), and $30.35 \%$ (writing). For grade 8, the following percentages of students achieved at least level 4: 40.37\% (reading), $25.25 \%$ (math), and $47.23 \%$ (writing). For grade 10, 32.60\% (reading), $15.09 \%$ (math), and $38.82 \%$ (writing) of students achieved at or above level 4. It is hypothesized that more competitive public education markets will be

\footnotetext{
${ }^{14}$ The county average is calculated by taking the average of school districts.
} 
Table 1

Percentage of students achieving at or above performance level 4: summary statistics

\begin{tabular}{lccc}
\hline & Grade 4 & Grade 8 & Grade 10 \\
\hline Reading & & & \\
Mean & 21.58 & 40.37 & 32.60 \\
Median & 21.00 & 41.00 & 32.00 \\
Maximum & 35.00 & 68.00 & 50.00 \\
Minimum & 11.00 & 22.00 & 17.00 \\
Standard deviation & 5.47 & 8.87 & 7.70 \\
Observations & 58 & 57 & 57 \\
Math & & & \\
Mean & 29.23 & 25.25 & 15.09 \\
Median & 29.00 & 26.00 & 14.00 \\
Maximum & 52.00 & 49.00 & 30.00 \\
Minimum & 15.00 & 9.00 & 6.00 \\
Standard deviation & 7.66 & 8.37 & 5.51 \\
Observations & 57 & 57 & 57 \\
Writing & & & \\
Mean & 30.35 & 47.23 & 38.82 \\
Median & 39.00 & 48.00 & 39.00 \\
Maximum & 56.00 & 71.00 & 56.00 \\
Minimum & 19.00 & 28.00 & 19.00 \\
Standard deviation & 7.86 & 8.79 & 7.86 \\
Observations & 57 & 57 & 57 \\
\hline
\end{tabular}

those with higher percentages of students achieving at or above performance level 4 .

\subsection{Competition measures}

Studies have concluded that greater competition yields higher student performance. Borland and Howsen (1992) examine whether public school competition improves school performance, where the Herfindahl index based on school districts within a county measures competition. Average scores for reading, language, and math for thirdgrade students within a school district measure school performance based on 170 school districts in Kentucky during 1989-1990. Greater competition is found to yield higher student performance and lower teacher salaries. Borland and Howsen (1993), in a re-test of Borland and Howsen (1992), find that a Herfindahl score of 0.50 is a critical threshold which, assuming an even distribution of students across school districts, means that two districts make a competitive market. Thus, test score gains from competition do not require many schooling choices.

Blair and Staley (1995) examine whether competition from neighboring school districts exerts a positive influence on local school performance. They examine 266 school districts in the six largest metropolitan areas of Ohio and measure performance as a composite index of mean scores for reading, mathematics, and language arts among students in the fourth, sixth and eighth grades. The primary measure of competition is the average test score in contiguous school districts, based on the hypothesis that nearby school districts that perform well exert beneficial effects on local performance. They find that higher performance of adjacent districts exerts a positive effect on performance in the subject district, thus indicating that beneficial effects on adjacent districts are provided when a school district becomes more competitive on the basis of test scores.

Hoxby (1994) examines how expanding public school choice in metropolitan areas would influence school performance. She expands choice by using exogenous variation in the concentration of school districts measured by the Herfindahl index on enrollment shares. Easier choice is found to lower per-pupil spending, lower teacher salaries, and expand class sizes. However, the same areas also exhibit higher average student performance, thus indicating that greater competition fosters higher-quality education.

Marlow (1997) examines whether competition measured by numbers of school districts and schools exerts beneficial effects on student performance. This crossstate study measures performance by average SAT scores, eighth-grade mathematics proficiency, and high school drop-out rates over 1988-1990. Greater competition through greater numbers of school districts is found to raise public education spending, but greater competition also is found to promote higher student achievement.

Zanzig (1997) examines whether greater competition among school districts improves public school performance using 1970 data on 337 school districts in California. Student achievement is measured by test scores of high-school seniors (arithmetic portion of the Iowa Tests of Educational Development). Two alternative measures of competition are examined: the Herfindahl index and number of school districts per county. Greater competition is found to improve student achievement, and it takes between three and five school districts to make a completely competitive education market. That is, test scores rise with numbers of school districts, with a point of saturation reached between three and four districts a minimum of three districts is necessary to reach the competitive threshold. Thus, Zanzig (1997) concludes that counties that have one or two school districts should consider restructuring their school system into three or more districts if they are interested in improving student achievement.

The present study measures public school market competition by the Herfindahl index as this measure appears to have become the measure of choice in the literature. California provides a rich data set with its 57 counties and over 1000 school districts. It is appropriate to use counties as the unit of observation since California school districts are organized within counties and overseen by county boards of education, all of which are elected except for Los Angeles county's board which is 
appointed by its Board of Supervisors. The Herfindahl index is the sum of squared shares in each market and therefore has a minimum value of near 0 and a maximum value of 1 . Lower values indicate competitive markets and, at the extreme value of one, a perfect monopoly since this means that a sole firm controls the market.

Three Herfindahl index measures are calculated one for each grade level of performance data. Separate calculations for each grade level begin by determining which schools offer the particular grade level. Enrollment at this grade level for each school district is then determined, followed by calculation of its share of total county enrollment. The square of each school district's share of total county enrollment at this grade level is then summed to provide the Herfindahl score.

Table 2 displays summary statistics for the three Herfindahl index calculations. Mean Herfindahl scores are 0.32 (fourth grade), 0.32 (eighth grade) and 0.42 (tenth grade). The higher value for the tenth grade is not surprising since there tend to be many more elementary schools than there are high schools, thus fostering more schooling choices at lower-grade levels than at the higher-grade levels. The Herfindahl scores indicate that lower-grade levels therefore provide more competitive environments than do higher-grade levels.

\section{Spending and performance equations ${ }^{15}$}

The following models of cross-county spending and performance equations are estimated:

$$
\text { EXP }_{i}=f\left(Y_{i}, \text { DENSITY }_{i}, \text { STUDENT }_{i}, \text { STATE }_{i},\right.
$$$$
\text { FEDERAL }_{i}, \text { BLACK }_{i}, \operatorname{HISPANIC}_{i}, \operatorname{ASIAN}_{i}, \mathrm{HERF}_{i} \text { ) }
$$

Table 2

Herfindahl scores: summary statistics

\begin{tabular}{lccc}
\hline & Grade 4 & Grade 8 & Grade 10 \\
\hline Mean & 0.32 & 0.31 & 0.42 \\
Median & 0.19 & 0.20 & 0.32 \\
Maximum & 1.00 & 1.00 & 1.00 \\
Minimum & 0.06 & 0.06 & 0.08 \\
Standard deviation & 0.29 & 0.28 & 0.27 \\
Observations & 58 & 58 & 58 \\
\hline
\end{tabular}

\footnotetext{
${ }^{15}$ An alternative empirical approach is to estimate frontier production functions that provide information on the level of efficiency that public schools obtain. Cooper and Cohn (1997) develop this approach and demonstrate how its use on data on public school classes in South Carolina result in different results than when the "educational production function" approach (e.g., that used in the present paper) is used.
}

and

$$
\begin{gathered}
\text { PERF }_{i}=f\left(\text { EXP }_{i}, Y_{i}, \text { DENSITY }_{i}, \operatorname{STATE}_{i}, \text { FEDERAL }_{i},\right. \\
\text { BLACK } \left._{i}, \text { HISPANIC }_{i}, \text { ASIAN }_{i}, \operatorname{HERF}_{i}\right),
\end{gathered}
$$

where

$\mathrm{EXP}_{i}=$ education spending per pupil at the primary and secondary levels, in dollars

$Y_{i} \quad=$ per capita personal income, in dollars

DENSITY $_{i}=$ population divided by square miles

STUDENT $_{i}=$ student share of the population

STATE $_{i}=$ state share of education funding

FEDERAL $_{i}=$ federal share of education funding

BLACK $_{i}=$ Black percentage share of student population

HISPANIC $_{i}=$ Hispanic percentage share of student population

$\operatorname{ASIAN}_{i}=$ Asian percentage share of student population HERF $_{i}=$ Herfindahl index score

$\mathrm{PERF}_{i}$ = reading, writing, and math achievement, and teacher-student ratios

Eq. (1) regresses education spending per pupil on the following factors. Per capita personal income is expected to exert a positive influence on spending when it reflects the county's demand for education funding. Population density is expected to exert a positive influence on spending since it is often argued that more urban areas have higher costs than more rural areas. Duncombe and Yinger (1997), for example, argue that inner-city schools costs more, but they also are more inefficient when given additional state aid than schools not located in the inner city. The student share of the population would exert a positive influence on spending when it influences the strength of the demand for education spending by parents. On the other hand, an increase in the students' share might increase the tax price of education, thus possibly reducing the demand for education by taxpayers. Two studies find that voter age influences public spending on education. Miller (1996) finds that parents of school-age children have exerted an increasing positive influence on public school spending. Poterba (1997) finds that an increase in the fraction of elderly residents in a state is associated with a significant reduction in per-child educational spending on K-12 education.

Shares of funding through state and federal revenues may exert two opposed effects on spending. One potential effect follows the Brennan and Buchanan (1980) hypothesis that more centralized funding causes taxpayers to perceive tax burdens to be lower than when all funding is local. Under this view, greater use of state and/or federal funding will cause voters to demand more spending under the fiscal illusion that it is cheaper than 
local funding and therefore a positive relationship between state and federal shares of funding and education spending would follow. The other potential effect is a product of California's effort to equalize spending across school districts. With these efforts, we should expect that greater funding through state and federal sources would be targeted to those school districts with relatively few financial resources. Therefore, if this occurs, then higher shares of state and federal funding will be related to relatively low levels of spending simply because these jurisdictions would normally have relatively small spending levels as a result of being relatively poor. Given that equalization efforts have been fought by richer districts and supplemented by other financing sources, higher shares of state and federal funding would tend to rise in jurisdictions that tend to spend relatively less on education. Given these two potential and offsetting effects on education spending, the net effect remains an empirical question to be resolved through estimation.

The public exchange view predicts that more concentrated districts would have higher spending since policy makers in the more-concentrated districts enjoy greater monopoly power than those in less-concentrated districts. The alternative view is that because greater concentration allows greater scale economies, there will be a negative relation between Herfindahl scores and spending. These two predictions are therefore opposite in direction and the net effect is an empirical matter.

Eq. (2) regresses performance measures on various factors. Performance is measured four ways: percentage of students achieving at or above performance level 4 in reading, math and writing, and the teacher-student ratio. Expenditures per pupil are expected to exert a positive effect on performance according to the conventional view. But, as discussed previously, bureaucracy theory suggests that higher spending by itself need not filter down to higher performance. The connection between education spending and program quality is therefore ambiguous: higher spending could simply reflect higher costs with little connection to higher performance due to higher monopoly power, or it could also reflect higherquality school programs. The net effect remains an empirical question.

Per capita income is expected to exert a positive influence on performance since it is commonly believed that income and educational achievement are positively related. That is, the higher are parents' income, the higher will be the demand for quality education as measured by higher test achievement or small class sizes. Population density controls for the effect of urbanization on performance and it is often believed that greater density leads to lower performance. State and federal shares of funding control for whether non-local funding influences performance.

Median education is expected to exert a positive influence on performance based on the assumption that the higher is local educational attainment, the greater the demand for high academic achievement of local children. The percentages of student populations that are Black, Hispanic or Asian are additional control variables that might explain variation in performance. Sander (1992) finds that ethnic and religious effects on educational attainment are partly explained by differentials in parental endowments such as parents' schooling and father's occupation.

Herfindahl scores are expected to negatively influence test achievement under the public exchange model since higher values reflect less competition in the public education market. A positive relationship is predicted by the alternative view that greater concentration allows greater scale economies that then allow more spending dollars to be diverted to those areas that most benefit students. For example, scale economies might allow highly concentrated school districts to offer greater variety of courses, better facilities or other means of fostering student achievement. Once again, there are potentially opposing effects on student achievement from this monopoly power variable and actual effects remain empirical issues.

Herfindahl scores are expected to negatively affect the teacher-student ratio under the public exchange model when parents strongly believe that smaller class sizes are an important component to school performance. Even if policy makers do not believe that lowering class size will raise student achievement, the public exchange model predicts that they have little choice but to conform to these parental preferences when they operate in competitive education markets. That is, Herfindahl scores should be negatively related to teacher-student ratios. Moreover, as discussed previously, if administrators and staff prefer to receive income in the form of salary and benefits rather than in smaller class sizes, they may also prefer larger class sizes as the hiring of additional teachers means fewer dollars for themselves. If true, this also means that less-competitive markets allow this preference to be more fully exploited, thus suggesting once again that, as markets become less competitive as reflected by higher Herfindahl scores, teacher-student ratios should fall. However, it is not clear that public opinion will allow significant hikes in salaries, and therefore higher compensation may arise in other areas such as benefits, paid holidays, etc.

An alternative view is that more teachers (per student) may be hired with cost savings that follow higher scale economies associated with higher Herfindahl scores. This view assumes that policy makers do not exploit monopoly powers along the lines of bureaucracy theory and that policy makers believe that smaller class sizes are useful outlets for cost savings that arise from scale economies associated with relatively concentrated education markets. A positive relationship between Herfindahl scores and teacher-student ratios is predicted under 
these assumptions. The relation between Herfindahl scores and teacher-student ratios is therefore ambiguous.

Data for these variables are available for most counties during 1993. Two sparsely populated counties did not participate in many of the data collection efforts of the California Department of Education, thus providing from 53 to 55 observations out of the 57 counties. Significance of estimated coefficients is based on two-tailed tests at $0.01,0.05$, and 0.10 levels.

The California Department of Education provides raw data at the level of school districts. These data were then aggregated to the county level and then compiled into a master file with data collected from other sources. Data at the county level collected from the California Statistical Abstract of 1996 are: per capita income, population, and median numbers of years of schooling (only available for 1990).

Table 3 displays summary statistics of the data that have not already been discussed in Table 1 (student achievement) and Table 2 (Herfindahl scores). Education spending per pupil averages $\$ 4188.70$, with a range of $\$ 5357.82$ to $\$ 3529.21$. As evidence of the spending equalization effort, the state share of funding variable averages 0.57 , with a range of 0.80 to 0.18 , thus indicating a wide range of state support. The federal share of funding averages 0.06 , and with a range of 0.02 to 0.11 indicates the relatively small role of the federal government in attempting to equalize school spending through expending its own dollars. The racial mix of student populations show high diversity: Black (4.09\% average, with range of $0 \%$ to $22.89 \%$ ), Hispanic (23.58\% average, with range of $1.99 \%$ to $78.65 \%$ ) and Asian (5.04\% average, with range of $0 \%$ to $38.75 \%$ ).

\section{SUR estimation}

\subsection{Education spending per pupil and performance equations}

The seemingly unrelated regression (SUR) method estimates the parameters of the system of spending and performance equations by accounting for contemporaneous correlation in the errors across equations. This is a recursive model that consists of a series of endogenous variables that are considered as a group because they appear to bear a close conceptual relationship to one another. Spending, measures of student performance (reading, math, and writing), and teacher-student ratios are often grouped together as indicators of public school performance by both the public and educators and therefore the SUR technique appears to be appropriate here. Relationships between these equations are indicated when the error terms of these equations are correlated and, in this case, the SUR model allows for more efficient estimates than would arise under estimation by ordinary least squares. As Pindyck and Rubinfeld (1991, p. 310) discuss, SUR estimation is basically a two-stage estimation procedure that results in consistent and asymptotically efficient estimates.

Table 4 displays SURs of education spending and fourth-grade performance equations. In the spending equation, only the Herfindahl score exerts a statistically significant effect - a positive effect, as hypothesized by the public exchange view that higher monopoly power leads to higher spending. In the reading achievement equation, education spending exerts a positive, but weakly significant $(0.10$ level) effect, thus indicating that higher spending improves reading achievement. Median

Table 3

Summary statistics of remaining variables

\begin{tabular}{|c|c|c|c|c|}
\hline Variable & Mean & Minimum & Maximum & Standard deviation \\
\hline Education spending per student & 4188.79 & 3529.21 & 5357.82 & 297.13 \\
\hline Per capita income & $19,267.25$ & 12,776 & 38,687 & 4790.10 \\
\hline Population density & 470.75 & 1.81 & 15805.14 & 1601.28 \\
\hline Teacher-student ratio & 0.05 & 0.04 & 0.06 & 0.006 \\
\hline Student share of population & 0.18 & 0.08 & 0.25 & 0.03 \\
\hline State share of funding & 0.57 & 0.18 & 0.80 & 0.15 \\
\hline Federal share of funding & 0.06 & 0.02 & 0.11 & 0.02 \\
\hline Median education & 13.22 & 12.20 & 15.40 & 0.64 \\
\hline Black student percentage & 4.09 & 0.00 & 22.89 & 4.95 \\
\hline Hispanic student percentage & 23.58 & 1.99 & 78.65 & 17.43 \\
\hline Asian student percentage & 5.04 & 0.00 & 38.75 & 6.55 \\
\hline
\end{tabular}


Table 4

SUR estimations of education spending and fourth-grade performance (education spending: per pupil)

\begin{tabular}{|c|c|c|c|c|c|}
\hline & Education spending & Reading & Math & Writing & $\begin{array}{l}\text { Teacher- } \\
\text { student ratio }\end{array}$ \\
\hline \multirow[t]{2}{*}{ Constant } & $3224.96^{\mathrm{a}}$ & $-62.52^{\mathrm{a}}$ & $-61.31^{\mathrm{a}}$ & $-73.42^{\mathrm{a}}$ & -0.02 \\
\hline & 4.85 & 3.86 & 2.86 & 3.72 & 0.70 \\
\hline \multirow[t]{2}{*}{ Education spending } & & $0.002^{\mathrm{c}}$ & -0.001 & 0.002 & $1.24 \times 10^{-5 a}$ \\
\hline & & 1.60 & 0.84 & 1.41 & 6.88 \\
\hline \multirow[t]{2}{*}{ Per capita income } & 0.03 & -0.0001 & $0.0004^{\mathrm{c}}$ & -0.0003 & $-1.9 \times 10^{-7}$ \\
\hline & 1.56 & 0.74 & 1.85 & 1.18 & 0.61 \\
\hline \multirow[t]{2}{*}{ Population density } & 0.03 & 0.001 & 0.001 & 0.002 & $-3.8 \times 10^{-6 a}$ \\
\hline & 0.027 & 1.07 & 1.45 & 1.20 & 3.05 \\
\hline \multirow[t]{2}{*}{ Student share of population } & -11.30 & & & & \\
\hline & 0.01 & 0.01 & 0.01 & 0.01 & 0.01 \\
\hline \multirow[t]{2}{*}{ State share of funding } & 103.66 & -5.59 & 5.09 & -4.58 & $-7.4 \times 10^{-5}$ \\
\hline & 0.18 & 1.20 & 0.94 & 0.81 & 0.01 \\
\hline \multirow[t]{2}{*}{ Federal share of funding } & 4783.16 & -20.99 & -30.73 & -44.09 & -0.07 \\
\hline & 1.40 & 0.61 & 0.74 & 1.06 & 1.59 \\
\hline \multirow[t]{2}{*}{$\%$ Black } & & -0.12 & $-0.47^{\mathrm{a}}$ & -0.10 & \\
\hline & 1.59 & 1.15 & 3.81 & 0.73 & 0.73 \\
\hline \multirow[t]{2}{*}{$\%$ Hispanic } & & -0.01 & $-0.13^{\mathrm{a}}$ & -0.03 & \\
\hline & 0.73 & 0.36 & 3.78 & 0.85 & 0.85 \\
\hline \multirow[t]{2}{*}{$\%$ Asian } & & 0.01 & -0.20 & -0.04 & \\
\hline & 0.85 & 0.09 & 1.39 & 0.26 & 0.26 \\
\hline \multirow[t]{2}{*}{ Median education } & & $6.49^{\mathrm{a}}$ & $6.97^{\mathrm{a}}$ & $8.24^{\mathrm{a}}$ & 0.002 \\
\hline & & 4.79 & 4.25 & 5.01 & 0.77 \\
\hline \multirow[t]{2}{*}{ Herfindahl } & $545.92^{\mathrm{a}}$ & $-4.13^{\mathrm{b}}$ & -1.45 & $-3.38^{c}$ & $0.01^{\mathrm{c}}$ \\
\hline & 2.65 & 2.46 & 0.71 & 1.66 & 1.81 \\
\hline$R^{2}$ adjusted & 0.07 & 0.72 & 0.80 & 0.71 & 0.56 \\
\hline S.e.e. & 375.73 & 2.94 & 3.45 & 3.57 & 0.01 \\
\hline$N$ & 54 & 54 & 53 & 54 & 54 \\
\hline
\end{tabular}

a Significance at 0.01 level (two-tailed test).

b Significance at 0.05 level (two-tailed test).

c Significance at 0.10 level (two-tailed test).

education behaves according to expectations since it is found to exert a strongly positive and significant effect on reading achievement. The Herfindahl score is found to exert a significant and negative effect on reading achievement, thus providing evidence in support of the public exchange view that less competitive school systems have relatively lower achievement.

In the math achievement equation, significant effects are found for per capita income (positive, as expected), median education (positive, as expected), and percentages of Blacks and Hispanics in the student body (negative). Only median education (positive, as expected) and the Herfindahl score (negative, as predicted by the public exchange view) are found to exert significant influences on writing achievement. For the teacher-student ratio equation, education spending (positive), population density (negative), and the Herfindahl score (positive, but weakly significant at the 0.10 level) exert significant effects.

Table 5 displays SURs of education spending and eighth-grade performance equations. In the spending equation, only the Herfindahl score exerts a statistically significant effect - the positive effect hypothesized by the public exchange view. In the reading achievement equation, education spending exerts a negative and significant effect. While the Black and Hispanic percentages of student bodies are found to be negatively related to achievement, the Asian percentage exerts no significant effect. Median education exerts the hypothesized positive and significant effect on reading achievement. The Herfindahl score is found to exert a significant and negative effect on reading achievement, thus providing evidence in support of the public exchange view.

In the math achievement equation, education spending exerts a negative influence. Significant negative effects are found for the Black and Hispanic percentages of student bodies, but no effect is found for the Asian percentage. Median education (positive) and the Herfindahl score (negative) exert significant effects. In the writing achievement equation, education spending exerts a negative and significant effect. The federal share of funding exerts a negative and significant influence on perform- 
Table 5

SUR estimations of education spending and eighth-grade performance (education spending: per pupil)

\begin{tabular}{|c|c|c|c|c|c|}
\hline & Education spending & Reading & Math & Writing & $\begin{array}{l}\text { Teacher- } \\
\text { student ratio }\end{array}$ \\
\hline \multirow[t]{2}{*}{ Constant } & $3201.43^{\mathrm{a}}$ & 21.90 & $-47.91^{\mathrm{b}}$ & 23.92 & -0.01 \\
\hline & 4.92 & 0.71 & 2.10 & 0.83 & 0.60 \\
\hline \multirow[t]{2}{*}{ Education spending } & & $-0.01^{\mathrm{a}}$ & $-0.003^{c}$ & $-0.01^{\mathrm{a}}$ & $1.23 \times 10^{-5 \mathrm{a}}$ \\
\hline & & 3.64 & 1.75 & 2.79 & 6.71 \\
\hline \multirow[t]{2}{*}{ Per capita income } & 0.03 & 0.0003 & -0.0001 & $-1.1 \times 10^{-5}$ & $-2.1 \times 10^{-7}$ \\
\hline & 1.55 & 0.87 & 0.67 & 0.03 & 0.66 \\
\hline \multirow[t]{2}{*}{ Population density } & 0.04 & 0.001 & 0.001 & 0.0004 & $-3.7 \times 10^{-6 a}$ \\
\hline & 0.40 & 0.42 & 0.63 & 0.30 & 2.97 \\
\hline \multirow[t]{2}{*}{ Student share of population } & 24.75 & & & & \\
\hline & 0.01 & & & & \\
\hline \multirow[t]{2}{*}{ State share of funding } & 127.61 & -2.62 & -9.54 & -9.25 & -0.001 \\
\hline & 0.22 & 0.32 & 1.42 & 1.27 & 0.11 \\
\hline \multirow[t]{2}{*}{ Federal share of funding } & 4712.08 & -70.24 & -28.11 & $-110.24^{\mathrm{c}}$ & -0.07 \\
\hline & 1.40 & 1.13 & 0.57 & 1.94 & 1.57 \\
\hline \multirow[t]{2}{*}{$\%$ Black } & & $-0.39^{b}$ & $-0.38^{\mathrm{a}}$ & -0.24 & \\
\hline & & 2.03 & 2.48 & 1.40 & \\
\hline \multirow[t]{2}{*}{ \% Hispanic } & & $-0.16^{\mathrm{a}}$ & $-0.15^{\mathrm{a}}$ & $-0.17^{\mathrm{a}}$ & \\
\hline & & 3.16 & 3.59 & 3.67 & \\
\hline \multirow[t]{2}{*}{$\%$ Asian } & & 0.22 & -0.01 & $0.50^{\mathrm{b}}$ & \\
\hline & & 0.99 & 0.03 & 2.45 & \\
\hline \multirow[t]{2}{*}{ Median education } & & $4.17^{\mathrm{c}}$ & $7.79^{\mathrm{a}}$ & $4.70^{\mathrm{b}}$ & 0.001 \\
\hline & & 1.72 & 3.98 & 2.13 & 0.72 \\
\hline \multirow{2}{*}{ Herfindahl } & $626.84^{\mathrm{a}}$ & $-12.89^{\mathrm{a}}$ & $-10.85^{\mathrm{a}}$ & $-6.83^{\mathrm{b}}$ & 0.005 \\
\hline & 2.96 & 4.05 & 4.25 & 2.37 & 1.64 \\
\hline$R^{2}$ adjusted & 0.09 & 0.66 & 0.75 & 0.72 & 0.55 \\
\hline S.e.e. & 370.54 & 5.33 & 4.22 & 4.71 & 0.005 \\
\hline$N$ & 54 & 53 & 53 & & 54 \\
\hline
\end{tabular}

a Significance at 0.01 level (two-tailed test).

b Significance at 0.05 level (two-tailed test).

c Significance at 0.10 level (two-tailed test).

ance. Although the Black percentage share of the student body is unrelated to performance, the Hispanic percentage (negative) and the Asian percentage (positive) are significantly related to writing achievement. Median education (positive, as expected) and the Herfindahl score (negative, as predicted by the public exchange view) exert significant influences on writing achievement. For the teacher-student ratio equation, education spending (positive) and population density (negative) exert significant effects.

Table 6 displays SURs of education spending and 10th-grade performance equations. In the spending equation, the federal share of funding is found to exert a weak, but significant, effect on spending. The Herfindahl score exerts a statistically significant and positive effect. In the reading achievement equation, education spending exerts a negative and significant effect. Population density (positive) and median education (positive) also exert significant influences. In the math achievement equation, education spending exerts a negative influence on achievement. Significant negative effects are found for the Black and Hispanic percentages of student bodies. Median education (positive) exerts significant effects. In the writing achievement equation, only the federal share of funding (negative) and the Black percentage of the student body (negative) exert significant effects. As in all previous estimations of the teacher-student ratio equation, education spending (positive) and population density (negative) exert significant effects.

\subsection{Education spending per personal income and performance equations}

Spending per capita is often the barometer that the public and school finance authorities use to gage the adequacy of education resources because it focuses on resources allocated to "average" students. However, education spending as a share of the economy reflects the extent to which government controls overall resource allocation and is often the focus of tests of the Leviathan hypothesis because it better measures the extent to which 
Table 6

SUR estimations of education spending and tenth-grade performance (education spending: per pupil)

\begin{tabular}{|c|c|c|c|c|c|}
\hline & Education spending & Reading & Math & Writing & $\begin{array}{l}\text { Teacher- } \\
\text { student ratio }\end{array}$ \\
\hline \multirow[t]{2}{*}{ Constant } & $3117.78^{\mathrm{a}}$ & -5.57 & $-41.39^{b}$ & -11.64 & -0.02 \\
\hline & 4.52 & 0.17 & 1.99 & 0.34 & 0.59 \\
\hline \multirow[t]{2}{*}{ Education spending } & & $-0.01^{\mathrm{b}}$ & $-0.004^{\mathrm{a}}$ & 0.001 & $1.26 \times 10^{-5 a}$ \\
\hline & & 2.50 & 2.86 & 0.30 & 6.98 \\
\hline \multirow[t]{2}{*}{ Per capita income } & 0.03 & 0.0002 & $5.7 \times 10^{-5}$ & $8.1 \times 10^{-5}$ & $-1.9 \times 10^{-7}$ \\
\hline & 1.55 & 0.58 & 0.25 & 0.22 & 0.59 \\
\hline \multirow[t]{2}{*}{ Population density } & 0.06 & $0.004^{\mathrm{b}}$ & 0.001 & 0.002 & $-3.6 \times 10^{-6 a}$ \\
\hline & 0.58 & 2.33 & 1.50 & 1.39 & 2.79 \\
\hline \multirow[t]{2}{*}{ Student share of population } & -35.65 & & & & \\
\hline & 0.01 & & & & \\
\hline \multirow[t]{2}{*}{ State share of funding } & -47.82 & -9.99 & 6.28 & 13.21 & -0.002 \\
\hline & 0.08 & 1.25 & 1.26 & 1.64 & 0.33 \\
\hline \multirow[t]{2}{*}{ Federal share of funding } & $6490.81^{\mathrm{c}}$ & 35.21 & -42.27 & $-196.02^{\mathrm{a}}$ & -0.06 \\
\hline & 1.91 & 0.53 & 1.02 & 2.90 & 1.30 \\
\hline \multirow[t]{2}{*}{$\%$ Black } & & -0.27 & $-0.38^{\mathrm{a}}$ & $-0.37^{\mathrm{c}}$ & \\
\hline & & 1.37 & 3.03 & 1.84 & \\
\hline \multirow[t]{2}{*}{$\%$ Hispanic } & & -0.07 & $-0.06^{\mathrm{c}}$ & -0.08 & \\
\hline & & 1.42 & 1.78 & 1.51 & \\
\hline \multirow[t]{2}{*}{$\%$ Asian } & & 0.02 & 0.08 & 0.33 & \\
\hline & & 0.10 & 0.57 & 1.41 & \\
\hline \multirow[t]{2}{*}{ Median education } & & $4.81^{\mathrm{c}}$ & $5.52^{\mathrm{a}}$ & 3.87 & 0.001 \\
\hline & & 1.91 & 3.52 & 1.52 & 0.63 \\
\hline \multirow{2}{*}{ Herfindahl } & $580.02^{\mathrm{b}}$ & -1.89 & 1.57 & 3.78 & 0.004 \\
\hline & 2.54 & 0.54 & 0.72 & 1.07 & 1.36 \\
\hline$R^{2}$ adjusted & 0.05 & 0.54 & 0.64 & 0.50 & 0.55 \\
\hline S.e.e. & 377.59 & 5.34 & 3.30 & 5.36 & 0.005 \\
\hline$N$ & 54 & 53 & 53 & 53 & 54 \\
\hline
\end{tabular}

a Significance at 0.01 level (two-tailed test).

b Significance at 0.05 level (two-tailed test).

c Significance at 0.10 level (two-tailed test).

government takes resources away from private owners. ${ }^{16}$ The previous equations are now run with public education spending as a percentage of personal income substituted for spending per pupil. For 1993, public education in California at the primary and secondary levels averaged $4.22 \%$ of personal income, and ranged between $1.19 \%$ to $7.02 \%$. Interestingly, the simple correlation coefficient between education spending per personal income and education spending per pupil is only 0.17 .

Table 7 displays SUR estimations of education spending as a percentage of personal income and fourth-grade performance equations. In the spending equation, per capita income (negative), student share of population (positive), federal share of funding (positive), and the Herfindahl score (positive) exert statistically significant effects. In the reading achievement equation, only median education (positive) and the Herfindahl score (negative) are significantly related to achievement. In the

\footnotetext{
16 See Oates (1989) for a survey of this literature.
}

math achievement equation, education spending (negative), Black and Hispanic shares of student bodies (negative), and median education (positive) are found to exert significant influences. Only median education (positive) exerts a significant effect on writing achievement. Finally, education spending (positive), population density (negative), and the Herfindahl score (positive) are found to significantly affect teacher-student ratios.

Table 8 displays SUR estimations of education spending as a percentage of personal income and eighth-grade performance equations. In the spending equation, per capita income (negative), student share of population (positive), federal share of funding (positive), and the Herfindahl score (positive) exert statistically significant effects. In the reading achievement equation, education spending (negative), Black and Hispanic shares of student bodies (negative), Asian share of the student body (positive), and the Herfindahl score (negative) are significantly related to achievement. In the math achievement equation, Black and Hispanic shares of student bodies (negative), median education (positive), and the 
Table 7

SUR estimations of education spending and fourth-grade performance (education spending: percentage of personal income)

\begin{tabular}{|c|c|c|c|c|c|}
\hline & Education spending & Reading & Math & Writing & $\begin{array}{l}\text { Teacher- } \\
\text { student ratio }\end{array}$ \\
\hline \multirow[t]{2}{*}{ Constant } & 0.71 & $-69.93^{\mathrm{a}}$ & $-47.86^{\mathrm{b}}$ & $-84.26^{\mathrm{a}}$ & -0.02 \\
\hline & 0.80 & 3.71 & 2.18 & 3.69 & 0.44 \\
\hline \multirow[t]{2}{*}{ Education spending } & & 0.50 & $-1.46^{\mathrm{b}}$ & 0.69 & $0.002^{\mathrm{c}}$ \\
\hline & & 0.89 & 2.36 & 1.01 & 1.74 \\
\hline \multirow[t]{2}{*}{ Per capita income } & $-0.0001^{\mathrm{a}}$ & -0.0001 & 0.0003 & -0.0002 & $-2.2 \times 10^{-7}$ \\
\hline & 4.59 & 0.57 & 1.24 & 1.02 & 0.57 \\
\hline \multirow{2}{*}{ Population density } & $-6.1 \times 10^{-5}$ & 0.001 & 0.001 & 0.001 & $-2.9 \times 10^{-6 c}$ \\
\hline & 0.47 & 1.29 & 0.88 & 1.43 & 1.81 \\
\hline \multirow[t]{2}{*}{ Student share of population } & $28.36^{\mathrm{a}}$ & & & & \\
\hline & 9.13 & & & & \\
\hline \multirow[t]{2}{*}{ State share of funding } & -0.47 & -7.33 & 8.73 & -7.04 & -0.003 \\
\hline & 0.60 & 1.46 & 1.58 & 1.16 & 0.31 \\
\hline \multirow[t]{2}{*}{ Federal share of funding } & $9.40^{\mathrm{b}}$ & -7.37 & -34.53 & -28.28 & -0.02 \\
\hline & 2.05 & 0.22 & 0.86 & 0.71 & 0.41 \\
\hline \multirow[t]{2}{*}{$\%$ Black } & & -0.07 & $-0.50^{\mathrm{a}}$ & -0.03 & \\
\hline & & 0.66 & 4.07 & 0.19 & \\
\hline \multirow[t]{2}{*}{$\%$ Hispanic } & & -0.01 & $-0.11^{\mathrm{a}}$ & -0.02 & \\
\hline & & 0.17 & 3.39 & 0.65 & \\
\hline \multirow[t]{2}{*}{$\%$ Asian } & & -0.04 & -0.17 & -0.11 & \\
\hline & & 0.36 & 1.17 & 0.76 & \\
\hline \multirow[t]{2}{*}{ Median education } & & $7.36^{\mathrm{a}}$ & $6.11^{\mathrm{a}}$ & $9.36^{\mathrm{a}}$ & 0.004 \\
\hline & & 4.96 & 3.63 & 5.22 & 1.39 \\
\hline \multirow[t]{2}{*}{ Herfindahl } & $0.57^{\mathrm{b}}$ & $-3.34^{\mathrm{b}}$ & -0.38 & -2.62 & $0.01^{\mathrm{a}}$ \\
\hline & 2.05 & 2.03 & 0.19 & 1.31 & 3.09 \\
\hline$R^{2}$ adjusted & 0.88 & 0.71 & 0.82 & 0.70 & 0.28 \\
\hline S.e.e. & 0.51 & 3.02 & 3.30 & 3.64 & 0.01 \\
\hline$N$ & 54 & 54 & 53 & 54 & 54 \\
\hline
\end{tabular}

a Significance at 0.01 level (two-tailed test).

b Significance at 0.05 level (two-tailed test).

c Significance at 0.10 level (two-tailed test).

Herfindahl score (negative) exert significant effects. In the writing achievement equation, education spending (negative), federal share of funding (negative), Black and Hispanic shares of student bodies (negative), Asian share of the student body (positive), median education (positive), and the Herfindahl score (negative) are significantly related to achievement. Finally, education spending (positive), population density (negative), and the Herfindahl score (positive) are found to significantly affect the teacher-student ratios.

Table 9 displays SUR estimations of education spending as a percentage of personal income and tenth-grade performance equations. In the spending equation, per capita income (negative), student share of population (positive), federal share of funding (positive), and the Herfindahl score (positive) exert statistically significant effects. In the reading achievement equation, education spending (negative), population density (positive), and the Black share of the student body (negative) are significantly related to achievement. In the math achievement equation, education spending (negative), state shares of funding (positive), Black and Hispanic shares of student bodies (negative), and median education (positive) are significant influences. In the writing achievement equation, the federal share of funding (negative) and median education (positive) are significantly related to achievement. Only the Herfindahl score (positive) is significantly related to teacher-student ratios.

\section{Summary and conclusions}

The evidence supports several hypotheses. First, despite claims to the contrary by many advocates of public education, higher education spending does not appear to raise student achievement. When defined as spending per pupil, education spending exerts a negative influence on student achievement in five out of nine cases and, when defined as spending as a percentage of personal income, it exerts a negative effect on student achievement in five out of nine cases as well. Spending per pupil 
Table 8

SUR estimations of education spending and eighth-grade performance (education spending: percentage of personal income)

\begin{tabular}{|c|c|c|c|c|c|}
\hline & Education spending & Reading & Math & Writing & $\begin{array}{l}\text { Teacher- } \\
\text { student ratio }\end{array}$ \\
\hline \multirow[t]{2}{*}{ Constant } & 0.66 & 40.43 & -42.91 & 20.70 & -0.01 \\
\hline & 0.74 & 1.22 & 1.64 & 0.66 & 0.39 \\
\hline \multirow[t]{2}{*}{ Education spending } & & $-3.48^{\mathrm{a}}$ & -0.81 & $-1.44^{\mathrm{a}}$ & $0.002^{\mathrm{c}}$ \\
\hline & & 3.62 & 1.01 & 1.61 & 1.81 \\
\hline \multirow[t]{2}{*}{ Per capita income } & $-0.0001^{\mathrm{a}}$ & $-4.0 \times 10^{-6}$ & -0.0003 & -0.0002 & $-2.1 \times 10^{-7}$ \\
\hline & 4.71 & 0.01 & 0.97 & 0.60 & 0.54 \\
\hline \multirow[t]{2}{*}{ Population density } & $-4.52 \times 10^{-5}$ & -0.001 & 0.0004 & -0.0003 & $-2.7 \times 10^{-6 c}$ \\
\hline & 0.35 & 0.52 & 0.32 & 0.22 & 1.69 \\
\hline \multirow[t]{2}{*}{ Student share of population } & $29.06^{\mathrm{a}}$ & & & & \\
\hline & 9.46 & & & & \\
\hline \multirow[t]{2}{*}{ State share of funding } & -0.56 & 10.10 & -6.47 & -3.84 & -0.004 \\
\hline & 0.72 & 1.20 & 0.91 & 0.49 & 0.39 \\
\hline \multirow[t]{2}{*}{ Federal share of funding } & $9.35^{\mathrm{b}}$ & -92.20 & -46.48 & $-125.41^{b}$ & -0.02 \\
\hline & 2.04 & 1.51 & 1.03 & 2.17 & 0.40 \\
\hline \multirow[t]{2}{*}{$\%$ Black } & & $-0.62^{\mathrm{a}}$ & $-0.44^{\mathrm{a}}$ & $-0.34^{\mathrm{c}}$ & \\
\hline & & 3.25 & 2.85 & 1.93 & \\
\hline \multirow[t]{2}{*}{$\%$ Hispanic } & & $-0.16^{\mathrm{a}}$ & $-0.15^{\mathrm{a}}$ & $-0.17^{\mathrm{a}}$ & \\
\hline & & 3.16 & 3.66 & 3.63 & \\
\hline \multirow[t]{2}{*}{$\%$ Asian } & & $0.40^{\mathrm{c}}$ & 0.06 & $0.57^{\mathrm{a}}$ & \\
\hline & & 1.85 & 0.37 & 2.81 & \\
\hline \multirow[t]{2}{*}{ Median education } & & 1.77 & $6.91^{\mathrm{a}}$ & $3.90^{\mathrm{a}}$ & 0.004 \\
\hline & & 0.69 & 3.32 & 2.81 & 1.35 \\
\hline \multirow{2}{*}{ Herfindahl } & $0.57^{\mathrm{b}}$ & $-12.22^{\mathrm{a}}$ & $-11.97^{\mathrm{a}}$ & $-7.51^{\mathrm{b}}$ & $0.01^{\mathrm{a}}$ \\
\hline & 1.98 & 3.88 & 5.10 & 2.53 & 3.23 \\
\hline$R^{2}$ adjusted & 0.87 & 0.64 & 0.74 & 0.70 & 0.29 \\
\hline S.e.e. & 0.51 & 5.50 & 4.32 & 4.86 & 0.01 \\
\hline$N$ & 54 & 53 & 53 & 53 & 54 \\
\hline
\end{tabular}

a Significance at 0.01 level (two-tailed test).

b Significance at 0.05 level (two-tailed test).

c Significance at 0.10 level (two-tailed test).

was found to exert a positive influence in one case and, in the remaining seven cases, no significant influence was determined.

Second, education spending tends to be highest in those counties exhibiting highest monopoly power as measured by the Herfindahl index. This result supports the predictions of bureaucracy theory since the ability of public education markets to draw funding is positively related to their degree of monopoly power. This result may suggest why higher education spending is not found to raise academic achievement since the higher spending may simply flow to administrators, teachers and staff in ways that bear little connection to student achievement. While the empirical results show that education spending is positively related to teacher-student ratios, further study of where other dollars go, and what effects these have on student achievement, would be a useful addition to this study.

While the majority of empirical results indicate either no link or a perverse link between spending and performance, it is difficult to speculate about how performance might change if spending were cut across school districts in California. Perhaps, the inverse relation arises because high-spending districts tend to be districts with a certain set of characteristics, including monopoly power, political intrusions into district policies and procedures, and poor student performance. However, a literal reading of the empirical results suggests that spending reductions across all districts would lead to either no effect on student performance, or even improvements. Unfortunately, use of a simple cross-section of data does not allow us to distinguish between these competing hypotheses, whereas a panel of cross-sectional data might yield better understanding of this important policy issue.

Third, median education levels of county residents exert strong influences on student achievement in the majority of cases ( 15 out of 18 cases). These results are consistent with the conventional wisdom that family influences such as parental education and involvement play instrumental roles in the development of student achievement. However, there is little evidence that per capita income plays much of a role. However, median 
Table 9

SUR estimations of education spending and tenth-grade performance (education spending: percentage of personal income)

\begin{tabular}{|c|c|c|c|c|c|}
\hline & Education spending & Reading & Math & Writing & $\begin{array}{l}\text { Teacher- } \\
\text { student ratio }\end{array}$ \\
\hline \multirow[t]{2}{*}{ Constant } & 0.49 & -3.47 & -30.69 & -26.39 & -0.01 \\
\hline & 0.53 & 0.10 & 1.42 & 0.75 & 0.24 \\
\hline \multirow{2}{*}{ Education spending } & & $-2.09^{b}$ & $-2.03^{\mathrm{a}}$ & 1.18 & 0.002 \\
\hline & & 2.10 & 3.27 & 1.17 & 1.54 \\
\hline \multirow[t]{2}{*}{ Per capita income } & $-0.0001^{\mathrm{a}}$ & $-5.7 \times 10^{-5}$ & -0.0001 & 0.0001 & $2.2 \times 10^{-7}$ \\
\hline & 4.51 & 0.16 & 0.59 & 0.40 & 0.56 \\
\hline \multirow[t]{2}{*}{ Population density } & $-2.2 \times 10^{-5}$ & $0.003^{\mathrm{c}}$ & 0.001 & 0.002 & $-2.4 \times 10^{-6}$ \\
\hline & 0.17 & 1.70 & 0.67 & 1.61 & 1.47 \\
\hline \multirow[t]{2}{*}{ Student share of population } & $28.10^{\mathrm{a}}$ & & & & \\
\hline & 9.13 & & & & \\
\hline \multirow[t]{2}{*}{ State share of funding } & -0.53 & -3.85 & $12.73^{\mathrm{b}}$ & 9.59 & -0.001 \\
\hline & 0.69 & 0.46 & 2.47 & 1.14 & 0.73 \\
\hline \multirow[t]{2}{*}{ Federal share of funding } & $11.34^{\mathrm{b}}$ & 21.89 & -49.53 & $-196.46^{\mathrm{a}}$ & 0.01 \\
\hline & 2.52 & 0.33 & 1.20 & 2.93 & 0.15 \\
\hline \multirow[t]{2}{*}{$\%$ Black } & & $-0.35^{\mathrm{c}}$ & $-0.48^{\mathrm{a}}$ & -0.31 & \\
\hline & & 1.75 & 3.89 & 1.51 & \\
\hline \multirow[t]{2}{*}{$\%$ Hispanic } & & -0.06 & $-0.06^{\mathrm{c}}$ & -0.08 & \\
\hline & & 1.24 & 1.74 & 1.54 & \\
\hline \multirow[t]{2}{*}{$\%$ Asian } & & 0.10 & 0.17 & 0.28 & \\
\hline & & 0.44 & 1.17 & 1.19 & \\
\hline \multirow[t]{2}{*}{ Median education } & & 3.72 & $4.13^{\mathrm{b}}$ & $4.90^{\mathrm{c}}$ & 0.003 \\
\hline & & 1.39 & 2.48 & 1.81 & 1.15 \\
\hline \multirow[t]{2}{*}{ Herfindahl } & $0.71^{\mathrm{b}}$ & -1.37 & 2.43 & 2.76 & $0.01^{\mathrm{b}}$ \\
\hline & 2.36 & 0.39 & 1.11 & 0.77 & 2.55 \\
\hline$R^{2}$ adjusted & 0.88 & 0.55 & 0.64 & 0.51 & 0.23 \\
\hline S.e.e. & 0.50 & 5.29 & 3.27 & 5.36 & 0.01 \\
\hline$N$ & 54 & 53 & 53 & 53 & 54 \\
\hline
\end{tabular}

a Significance at 0.01 level (two-tailed test).

b Significance at 0.05 level (two-tailed test).

c Significance at 0.10 level (two-tailed test).

education and per capita income data are aggregated to the county level and therefore do not necessarily track the influence that a parent's education or income exerts on their own children. A more disaggregated analysis would clearly be helpful here in sorting out these parental influences. It should also be noted that such factors go beyond the usual scope of short-term policy reforms, and at best represent long-term reforms that might affect achievement.

Fourth, there is strong support (nine out of 12 cases) for the public exchange view that higher market power leads to lower student achievement in the fourth and eighth grades, and little support (one case out of six) for affecting achievement in the tenth grade. No evidence is found to support the hypothesis that higher market power raises performance. While the evidence appears to suggest that greatest benefits associated with greater choice in education providers arise during the formative years of schooling, this remains a conjecture at this point. Further research into why competitive structure appears to be more important in the lower levels would appear to be warranted.

\section{Acknowledgements}

I wish to thank three anonymous referees for comments that improved the paper.

\section{References}

Anderson, G. M., Shughart, W. F., \& Tollison, R. D. (1991). Educational achievement and the cost of bureaucacy. Journal of Economic Behavior and Organization, 15 (1), 29-45.

Betts, J. R. (1995). Does school quality matter? Evidence from the national longitudinal survey of youth. Review of Economics and Statistics, 77 (2), 231-250.

Betts, J. R. (1996). Do school resources matter only for older workers. Review of Economics and Statistics, 78 (4), 638652. 
Blair, J. P., \& Staley, S. (1995). Quality competition and public schools: further evidence. Economics of Education Review, 14 (2), 193-208.

Black, S. E., 1997. Do better schools matter? Parental valuation of elementary education. Research paper \#9729, Federal Reserve Bank of New York.

Borland, M., \& Howsen, R. (1992). Student academic achievement and the degree of market concentration in education. Economics of Education Review, 11 (1), 1-39.

Borland, M., \& Howsen, R. (1993). On the determination of the critical level of market concentration in education. Economics of Education Review, 12 (2), 165-169.

Brennan, G., \& Buchanan, J. M. (1980). The power to tax: Analytical foundations of a fiscal constitution. Cambridge: Cambridge University Press.

Brewer, D. J. (1996). Does more school district administration lower educational productivity? Some evidence on the "administrative blob" in New York public schools. Economics of Education Review, 15 (1), 111-124.

California Legislative Analyst's Office, 1995. California's school finance system. Sacramento, CA: Calfornia State Government.

Card, D., \& Krueger, A. B. (1992). Does school quality matter? Returns to education and the characteristics of public schools in the United States. Journal of Political Economy, 100 (1), 1-40.

Card, D., \& Krueger, A. B. (1996). Labor market effects of school quality: theory and evidence. In G. Burtless, The effect of school resources on student achievement and adult success (pp. 97-140). Washington, DC: Brookings Institution.

Couch, J. F., Shughart, W. F., \& Williams, A. L. (1993). Private school enrollment and public school performance. Public Choice, 76 (3), 301-312.

Cooper, S. T., \& Cohn, E. (1997). Estimation of a frontier production function for the South Carolina educational process. Economics of Education Research, 16 (3), 313-327.

Downes, T. A. (1996). An examination of the structure of governance in California school districts before and after proposition 13. Public Choice, 86 (3), 279-307.

Duncombe, W., \& Yinger, J. (1997). Why is it so hard to help central city schools? Journal of Policy Analysis and Management, 16 (1), 85-113.

Duplantis, M. M., Chandler, T. D., \& Geske, T. G. (1995). The growth and impact of teachers' unions in states without collective bargaining legislation. Economics of Education Review, 14 (2), 167-178.

Eberts, R. W., \& Stone, J. A. (1984). Unions and public schools. New York: Lexington Books.

Fischel, W. A. (1988). Did serrano cause proposition 13 ? National Tax Journal, 42 (3), 465-473.

Fisher, R. C., \& Wassmer, R. W. (1998). Structure of local government. Journal of Urban Economics, 43 (3), 444-471.

General Accounting Office (1997). State efforts to reduce funding gaps between poor and wealthy districts. Washington, DC: US Government.

Glass, G. V., \& Smith, M. L. (1978). Meta-analysis of research on the relationship of class-size and achievement. San Francisco, CA: Far West Laboratory for Educational Research and Development.

Grogger, J. (1996). School expenditures and post-schooling earnings: evidence from high school and beyond. Review of Economics and Statistics, 78 (4), 628-637.

Hanushek, E. A. (1986). The economics of schooling: production and efficiency in public schools. Journal of Economic Literature, 24 (4), 1141-1177.

Hanushek, E. A., 1998. The evidence on class size. Occasional paper 98-1, University of Rochester, NY.

Hanushek, E. A., Rivkin, S. G., \& Taylor, L. L. (1996). Aggregation and the estimated effects of school resources. Review of Economics and Statistics, 78 (4), 611-627.

Hamilton, B. W., \& Macauley, M. K. (1991). Determinants and consequences of the private-public school choice. Journal of Urban Economics, 29 (2), 282-294.

Hirschman, A. O. (1970). Exit, voice and loyalty. Cambridge, MA: Harvard University Press.

Hoxby, C. M., 1994. Does competition among public schools benefit students and taxpayers? NBER working paper no. 4979, Cambridge, MA.

Hoxby, C. M. (1996). How teachers' unions affect education production. Quarterly Journal of Economics, 111 (3), 671-718

Kenny, L. W., \& Schmidt, A. B. (1994). The decline in the number of school districts in the U.S.: 1950-1980. Public Choice, 79 (1), 1-18.

Kurth, M. M. (1987). Teachers' unions and excellence in education: an analysis of the decline in sat scores. Journal of Labor Research, 8 (3), 351-367.

Lott, J. R. (1987). The institutional arrangement of public education. Public Choice, 54 (1), 89-96.

Marlow, M. L. (1992). Intergovernmental competition, voice and exit options and the design of fiscal structure. Constitutional Political Economy, 3 (1), 73-87.

Marlow, M. L. (1997). Public education supply and student performance. Applied Economics, 29 (5), 617-626.

Martinez-Vazquez, J., \& Seaman, B. (1985). Private schooling and the tiebout hypothesis. Public Finance Quarterly, 13 (2), 293-318.

Martinez-Vazquez, J., Rider, M., \& Walker, M. B. (1997). Race and the structure of school districts in the united states. Journal of Urban Economics, 41 (2), 281-300.

Miller, C. (1996). Demographics and spending for public education: a test of indirect group influence. Economics of Education Review, 15 (2), 175-185.

Newmark, C. M. (1995). Another look at whether private schools influence public school quality: comment. Public Choice, 82 (3), 365-373.

Niskanen, W. A. Jr. (1971). Bureaucracy and representative government. Chicago, IL: Aldine-Atherton.

Oates, W. E. (1989). Searching for leviathan: a reply and some further reflections. American Economic Review, 79 (3), 578-583.

Pindyck, R. S., \& Rubinfeld, D. L. (1991). Econometric models and economic forecasts (3rd ed.). New York: McGraw Hill.

Poterba, J. M. (1997). Demographic structure and the political economy of public education. Journal of Policy Analysis and Management, 16 (1), 48-66.

Rivlin, A. M. (1992). Reviving the American dream: The economy, the states and the federal government. Washington, DC: Brookings Institution.

Sander, W. (1992). The effects of ethnicity and religion on edu- 
cational attainment. Economics of Education Review, 11 (1), 119-135.

Silva, F., \& Sonstelie, J. (1995). Did serrano cause a decline in school spending? National Tax Journal, 48 (2), 199-212.

Sonstelie, J. (1982). The welfare cost of free public schools. Journal of Political Economy, 90 (4), 794-808.

Summers, A., \& Wolfe, G. (1977). Do schools make a difference? American Economic Review, 67 (4), 639-652.

Tiebout, C. M. (1956). A pure theory of local expenditures. Journal of Political Economy, 64 (3), 416-424.

Wagner, R. E. (1992). Grazing the federal budgetary commons: the rational politics of budgetary irresponsibility. The Journal of Law and Politics, 9 (1), 105-119.

West, E. G. (1990). Public education via exclusive territories. Public Finance Quarterly, 18 (3), 371-394.

West, E. G., \& Palsson, H. (1988). Parental choice of school characteristics: estimation using state-wide data. Economic Inquiry, 26 (4), 725-740.

Zanzig, B. R. (1997). Measuring the impact of competition in local government education markets on the cognitive achievement of students. Economics of Education Review, 16 (4), 431-441. 